\title{
Measurement of trypsin in duodenal juice by radioimmunoassay
}

\author{
G LAKE-BAKAAR, S MCKAVANAGH, C E RUBIO, O EPSTEIN, \\ AND J A SUMMERFIELD
}

From the Academic Department of Medicine, Royal Free Hospital, London

SUMMARY Trypsin in duodenal aspirate and pure pancreatic juice samples has been measured by both radioimmunoassay and enzymatic methods. The radioimmunoassay has been shown to be specific and to detect trypsin in the presence of aprotinin (Trasylol). In duodenal juice samples from control subjects and from patients with primary biliary cirrhosis a good correlation was obtained between both immunoreactive trypsin concentration and trypsin activity. The immunoreactive trypsinogen concentration in pure pancreatic juice also correlated well with activated trypsin activity. The mean immunoreactive trypsin concentration and the concentration of enzymatically inert immunoreactive trypsin in duodenal juice samples from patients with primary biliary cirrhosis were significantly lower than controls, suggesting pancreatic hyposecretion in this disease. After five duodenal juice samples had been stored for three months at $-70^{\circ} \mathrm{C}$, immunoreactive trypsin concentration in samples stored without Trasylol were reduced by $12 \cdot 0 \pm 4 \cdot 2$ (mean $\pm S D$ ) times the concentration of samples stored in Trasylol. Trypsin autodegradation continues even at $-70^{\circ} \mathrm{C}$; Trasylol protects against this. Radioimmunoassay is a reliable method of trypsin estimation in duodenal juice and has advantages over conventional enzymatic analysis.

A radioimmunoassay technique is available for the measurement of trypsin in human serum. ${ }^{1}$ The present study describes the use of this assay for the measurement of trypsin in duodenal juice and in pure pancreatic juice and compares the radioimmunoassay with a conventional method of enzymatic analysis. Since the radioimmunoassay also detects inhibitor-bound trypsin, it can be used in the estimation of the enzyme in duodenal juice which has been stored in the presence of inhibitors. In the absence of inhibitors, trypsin is known to autodegrade. ${ }^{2}$ Unlike enzymatic methods, the radioimmunoassay will also detect inactive proenzymes; it can therefore be used to measure trypsinogen in pure pancreatic juice without prior activation with enterokinase. Finally, in an attempt to test the hypothesis that the conversion of trypsinogen to trypsin in the duodenum may be impaired in primary biliary cirrhosis because of the low intraduodenal bile acid concentrations, ${ }^{34}$ we have assayed the trypsin content of duodenal juice from patients with this disease by both methods simultaneously and compared the data with those from normal subjects.

Received for publication 11 December 1979

\section{Methods}

\section{CONTROLS}

Duodenal juice samples from 31 fasting subjects. (22 males; age 20-72 years) were collected after the intravenous administration of cholecystokinin-pancreoxymin (100 Crick-Harper-Raper, CHR, units Boots Co., Nottingham, UK) and secretin (100 units Boots Co.), via a single lumen Ryle's tube positioned fluoroscopically in the third part of the duodenum. The samples were collected over ice. At the end of the collection, an aliquot of duodenal juice was removed and diluted in Trasylol (1 in 4) for radioimmunoassay estimations. The enzymatic analysis of trypsin activity, and the radioimmunoassay, were performed within two hours. Pancreatic function as assessed by trypsin output in duodenal aspirate after stimulation $^{5}$ was normal in all 31 subjects.

PRIMARY BILIARY CIRRHOSIS

Six patients were studied (five females; age range 40-65 years), who were diagnosed on the basis of a compatible liver biopsy and positive antimitochondrial antibody tests. Duodenal juice samples were collected into $7 \frac{1}{2}$ minute aliquots for one hour after intravenous cholecystokinin-pancreozymin and secretin. 
PURE PANCREATIC JUICE

Samples of pure pancreatic juice were collected after cannulation of the pancreatic duct at endoscopy and stimulation of pancreatic secretion with either secretin or cholecystokinin-pancreozymin.

\section{TRYPSIN ESTIMATION}

Trypsin activity in duodenal juice was measured by a spectrophotometric method ${ }^{6}$ based on the rate of hydrolysis of p-tosyl-l-arginine methyl ester. Trypsinogen in pure pancreatic juice was assayed similarly, after activation by incubating at $37^{\circ} \mathrm{C}$ for $\mathbf{4 0}$ minutes with duodenal juice of known trypsin activity which had been diluted 1 in 20 with $46 \mathrm{mM}$ Tris buffer containing $33 \mathrm{mM} \mathrm{CaCl}, \mathrm{pH} 8.1$ for 40 minutes. $^{7}$ The trypsin activity in the duodenal juice sample used for activating the pure pancreatic juice samples was subtracted from the total.

Immunoreactive trypsin concentration was determined by radioimmunoassay (RIA-gnost Trypsin, Behringwerke, Marburg). Details of the assay and its use in the estimation of serum trypsin have been previously described. ${ }^{1}$ Preliminary results showed that tryptic activity in samples of duodenal juice from four normal subjects were completely inhibited by Trasylol at a dilution of 1 in 2 . As an additional precaution, all samples of duodenal juice were diluted 1 in 4 with Trasylol to ensure complete inhibition. Other dilutions were made with bovine serum albumin $(5 \mathrm{~g} \%)$.

Protein determinations were performed by the method of Lowry et al. ${ }^{8}$

\section{Results}

CROSS-REACTIVITY WITH TRASYLOL

The effect of Trasylol on the radioimmunoassay

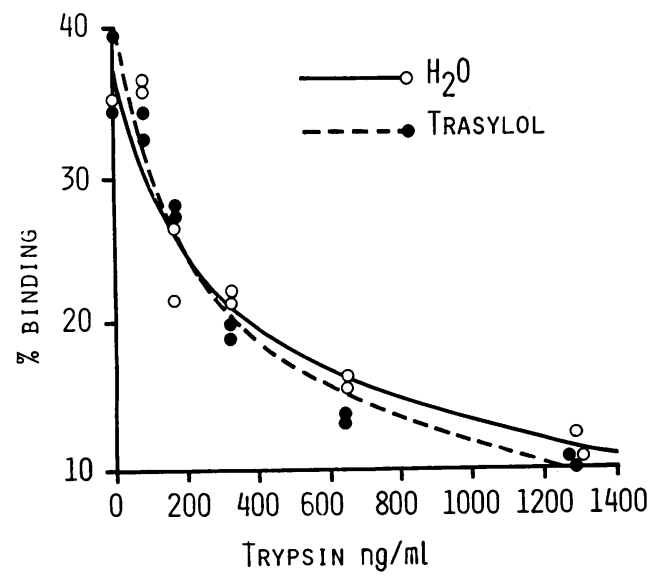

Fig. 1 Effect of Trasylol on trypsin radioimmunoassay. No cross-reactivity is shown with Trasylol. determination of trypsin is shown in Fig. 1. Lyophilised human trypsin standards were diluted in either distilled water or in Trasylol. The radioactivity from radiolabelled trypsin bound to antibody at increasing trypsin concentrations was similar both in the presence or absence of Trasylol. Trasylol therefore does not cross-react with the antibody under the assay conditions.

\section{ANTIBODY SPECIFICITY}

In an attempt to verify the specificity of the radioimmunoassay for trypsin, duodenal juice samples were used from which both trypsin and chymotrypsin had been removed by passage through an affinity column containing soybean trypsin inhibitor coupled to CNBr-activated Sepharose 4B (Pharmacia, Uppsala, Sweden). The column was eluted with $0.1 \mathrm{M} \mathrm{NaHCO}_{3}$ buffer containing $0.5 \mathrm{M} \mathrm{NaCl}$ at $\mathrm{pH} 7 \cdot 8$. The protein material eluted contained no tryptic activity. The percentage trace binding at increasing concentrations of protein material remained constant up to $68 \mu \mathrm{g}$ per $\mathrm{ml}$. Above this, a decrease in the amount of bound tracer was observed. At a protein concentration of $272 \mu \mathrm{g} / \mathrm{ml}$, $375 \mathrm{ng} / \mathrm{ml}$ of trypsin was detected by radioimmunoassay. The radioimmunoassay of trypsin in normal duodenal juice is usually performed at a 1 in 1000 dilution. At these high dilutions (total protein concentration approximately $1 \mu \mathrm{g} / \mathrm{ml}$ ), interference due to proteins other than trypsin would be minimal.

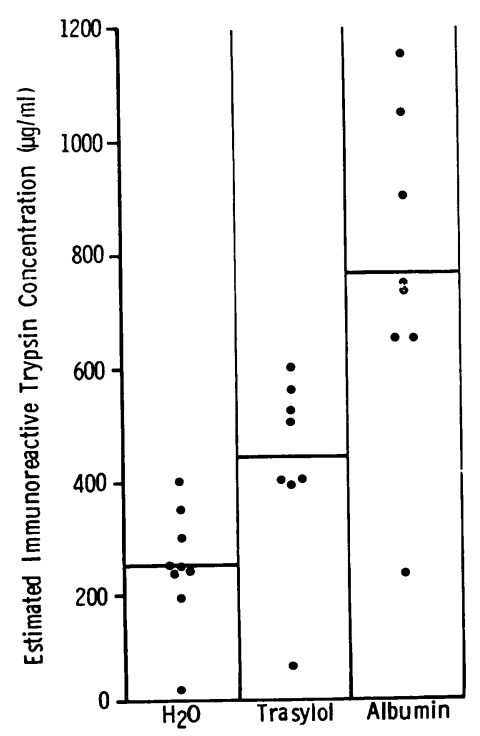

Fig. 2 Concentration of trypsin measured in samples of duodenal juice after dilution with distilled water. Trasylol, or albumin $(5 \mathrm{~g} / \mathrm{l})$. Trypsin concentration was highest in samples diluted with albumin. 
Chymotrypsin was eluted from the STI-sepharose column by the addition of tryptamine $(0.013 \mathrm{M})$ to the buffer. Even at concentrations of up to $736 \mu \mathrm{g} / \mathrm{ml}$, the mixture of purified human chymotrypsin and tryptamine did not affect the binding of antibody to radiolabelled trypsin.

\section{EFFECT OF PROTEIN}

The effect of varying concentrations of protein on the recovery of trypsin in duodenal juice by the radioimmunoassay was studied. A sample of duodenal juice was assayed after dilution in albumin solutions of varying concentrations, from 1 to $8 \mathrm{~g} / 100 \mathrm{ml}$. In five experiments the mean trypsin concentration measured was $358 \pm 38$ (mean \pm SD) and ranged from $320 \mu \mathrm{g} / \mathrm{ml}$ to $429 \mu \mathrm{g} / \mathrm{ml}$. Varying the concentration of protein between 1 and $8 \mathrm{~g} /$ $100 \mathrm{ml}$ does not appear to affect the measurement of trypsin in duodenal juice.

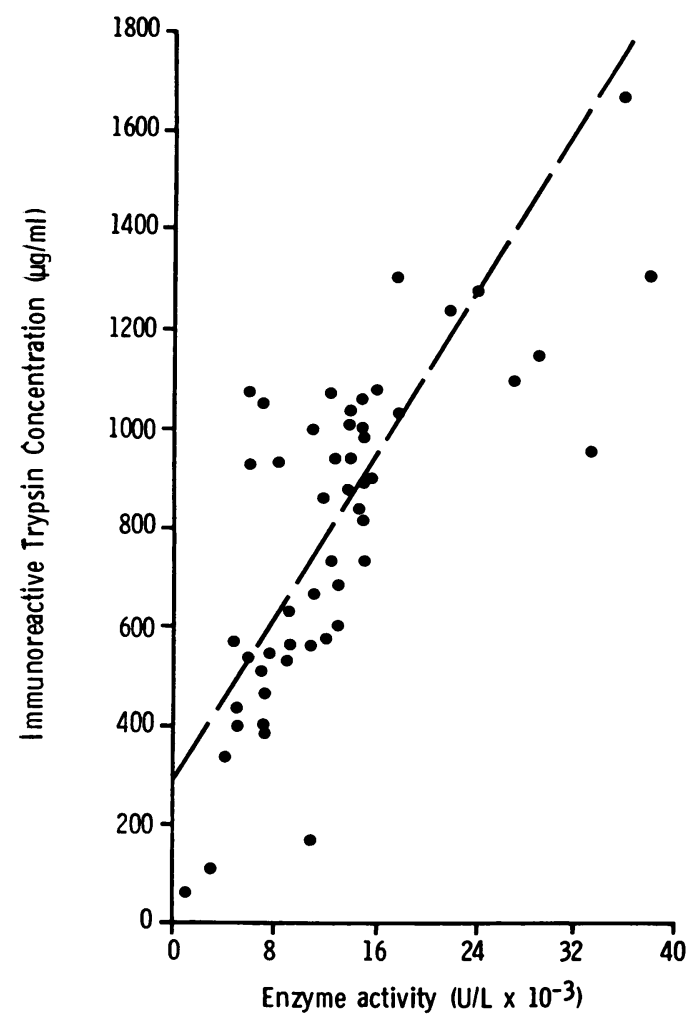

Fig. 3 Correlation between immunoreactive trypsin concentration and enzymatic activity in duodenal juice samples from controls $(\mathrm{r}=0.75, \mathrm{P}<0.001$,

$y=0.04 x+296 \cdot 1)$. Extrapolation of the regression line gives a y-intercept of $296 \mu \mathrm{g} / \mathrm{ml}$; this represents the concentration of enzymatically inert immunoreactive trypsin and is $32.5 \%$ of the mean total immunoreactive trypsin concentration, $912 \mu \mathrm{g} / \mathrm{ml}$.
EFFECT OF PROTEOLYSIS

In contrast to blood where the proteolytic activity of trypsin is inhibited by a large excess of serum inhibitors, trypsin in duodenal juice remains enzymatically active. Autodegradation might therefore interfere with the recovery of trypsin in duodenal juice.

Figure 2 shows the effect on trypsin recovery in duodenal juice of diluting the samples with distilled water, Trasylol or albumin $(5 \mathrm{~g} / \mathrm{l})$. In eight samples of duodenal juice, the mean immunoreactive trypsin concentration in the albumin diluted samples $767 \pm 284 \mu \mathrm{g} / \mathrm{ml}$ (mean $\pm \mathrm{SD})$ was significantly higher than in the samples diluted with Trasylol, $430 \pm 167$ $\mu \mathrm{g} / \mathrm{ml}$. These values were also significantly higher than in the samples diluted with distilled water, $247 \pm 111 \mu \mathrm{g} / \mathrm{ml}$. In three samples diluted with either albumin alone or albumin in Trasylol, similar concentrations of immunoreactive trypsin were detected.

\section{CORRELATION BETWEEN TRYPSIN \\ ACTIVITY AND IMMUNOREACTIVE TRYPSIN CONCENTRATION IN DUODENAL JUICE Controls}

Immunoreactive trypsin concentration and trypsin enzymatic activity have been measured in 56 samples of duodenal juice from 31 subjects without pancreatic disease.

A good correlation was observed between

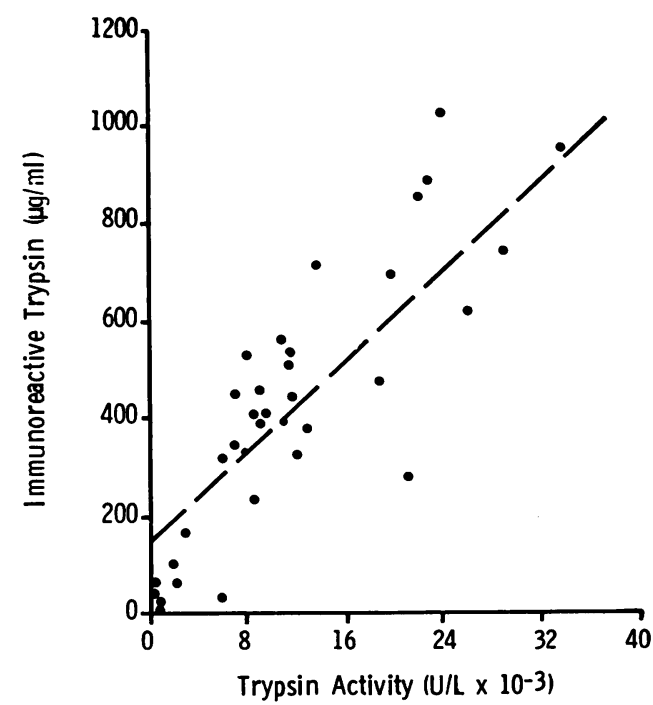

Fig. 4 Correlation between immunoreactive trypsin concentration and enzymatic activity in duodenal juice samples from patients with primary biliary cirrhosis $(\mathrm{r}=0.88, \mathrm{P}<0.001, y=0.023 x+148.5)$. The $y$-intercept, $148.5 \mu \mathrm{g} / \mathrm{ml}$, is $32.5 \%$ of the mean total immunoreactive trypsin concentration, $457 \mu \mathrm{g} / \mathrm{ml}$. 


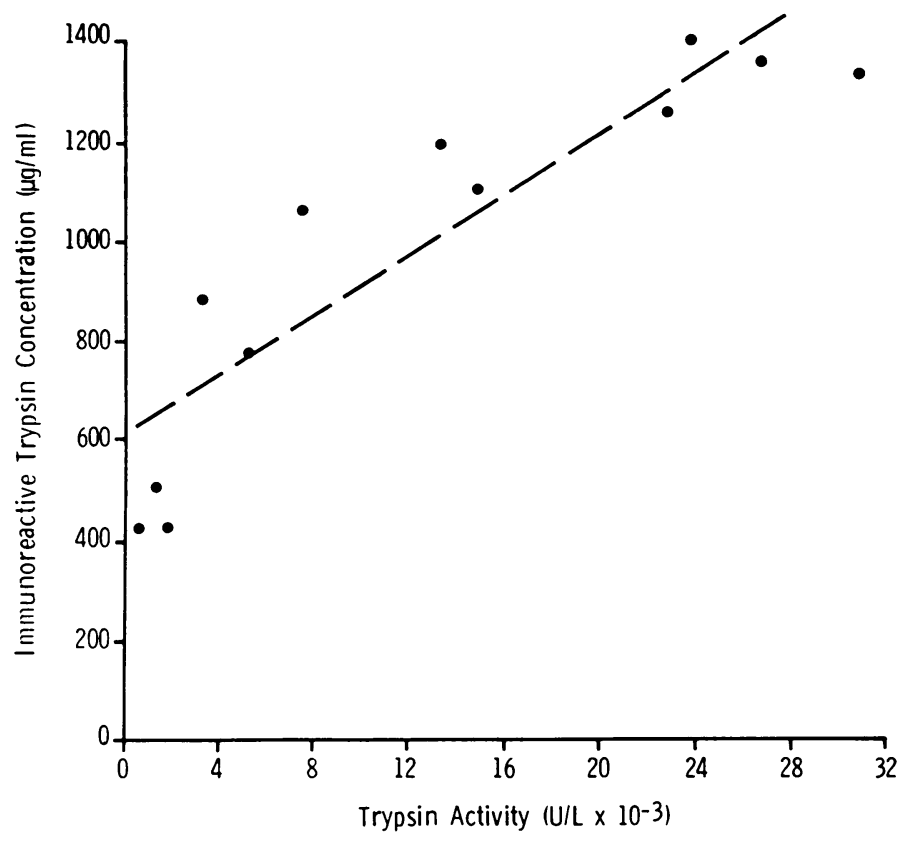

Fig. 5 Correlation between immunoreactive trypsinogen concentration and activated trypsin activity in pure pancreatic juice $(r=0.089, \mathrm{P}<0.001 ; y=0.03 x+607)$. The $y$ - intercept, $607 \mu \mathrm{g} / \mathrm{ml}$ represents $66.6 \%$ of the mean total immunoreactive trypsin concentration, $926 \mu \mathrm{g} / \mathrm{ml}$.

enzymatic activity and immunoreactive trypsin concentration $(r=0.75, \quad \mathrm{P}<0.001)$ in duodenal juice (Fig. 3). The equation of the linear regression line is given by $\mathrm{y}=0.04 \mathrm{x}+296 \cdot 1$, where $\mathrm{y}$ is the immunoreactive trypsin concentration and $\mathrm{x}$ is enzymatic activity. The intercept when $x=0, y=296 \mu \mathrm{g} / \mathrm{ml}$ may represent the amount of immunoreactive trypsin which is enzymatically inactive and may be either trypsin which is bound to inhibitors, inert trypsin, or trypsinogen.

\section{Primary biliary cirrhosis}

The normal conversion of trypsinogen to trypsin by enterokinase requires the presence of bile and bile acids. ${ }^{347}$ In the absence of bile acids in the duodenum in children with biliary atresia, abnormally low trypsin activities were found in duodenal aspirate, whereas chymotrypsin activity was normal. This was thought to represent incomplete trypsinogen activation. ${ }^{3}$ In 35 samples of duodenal juice collected from six patients with primary biliary cirrhosis, a good correlation was found between immunoreactive trypsin concentration and trypsin activity ( $r=0.88, \mathrm{P}<0.001)$ (Fig. 4). On extrapolation of the regression line to the ordinate, a value of $148.5 \mu \mathrm{g} / \mathrm{ml}$ was obtained for the immunoreactive trypsin concentration in duodenal juice with zero trypsin activity. The mean concentration of immunoreactive trypsin, $457 \pm 306 \mu \mathrm{g} / \mathrm{ml}$ in this group, was significantly lower than the control, $912 \pm 540$ $\mu \mathrm{g} / \mathrm{ml}(t=4 \cdot 54, \mathrm{P}<0.001)$ (unpaired Student's $t$ test).

\section{Pure pancreatic juice}

In 12 samples of pure pancreatic juice, a good correlation was obtained between immunoreactive trypsin concentration and trypsin activity after

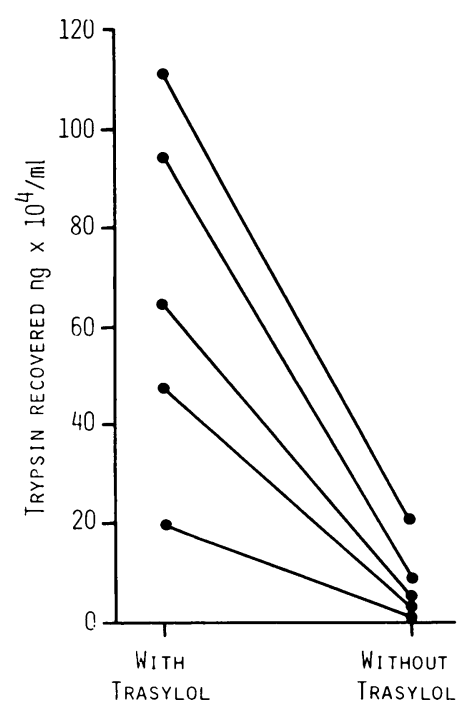

Fig. 6 Immunoreactive trypsin recovery in duodenal juice stored for up to three months with and without Trasylol. The concentrations measured were approximately 12 times higher in the Trasylol stored samples. 
activation $(r=0.89, \mathrm{P}<0.001)$ (Fig. 5). The intercept of the regression line when trypsin activity was zero gave the equivalent concentration of immunoreactive trypsin as $607 \mu \mathrm{g} / \mathrm{ml}$. The mean immunoreactive trypsin concentration in the pure pancreatic juice samples, $926 \pm 39 \mu \mathrm{g} / \mathrm{ml}$, did not differ significantly from the duodenal juice samples from controls, $912 \pm 540 \mu \mathrm{g} / \mathrm{ml} \quad(t=0.09, \quad \mathbf{P}<0.4$; unpaired Student's $t$ test).

\section{Effect of storage at $-70^{\circ} \mathrm{C}$}

Aliquots of duodenal juice were stored at $-70^{\circ} \mathrm{C}$ for three months, with and without Trasylol. Trypsin concentration was then measured in the samples by radioimmunoassay. Results are shown in Fig. 6. The concentrations of immunoreactive trypsin measured in the five samples stored in Trasylol were $12 \cdot 0 \pm \mathbf{4 \cdot 2}$ (mean \pm SD) times higher than in identical samples stored without Trasylol. Trasylol thus appears to offer protection against autodegradation which can occur even at $-70^{\circ} \mathrm{C}$.

\section{Discussion}

These results confirm that measurement of duodenal juice trypsin by radioimmunoassay is a useful alternative to enzymatic analysis. Our data, like the findings of Temler and Felber, ${ }^{9}$ confirm that inhibition of the catalytic activity of trypsin does not interfere with its immunoreactivity. The radioimmunoassay therefore offers two major advantages. Firstly, trypsin can be estimated in duodenal juice which has been stored in Trasylol to eliminate autodegradation. Secondly, as the inactive zymogen can also be measured, trypsinogen in pure pancreatic juice can be estimated directly without the need for prior activation.

The loss of immunoreactive trypsin in the samples of duodenal juice stored at $-70^{\circ} \mathrm{C}$ without Trasylol was unexpected. It suggests that significant proteolytic activity continues even at this low temperature. Lyophilised samples of trypsin have previously been observed to show slow autodigestion at $4^{\circ} \mathrm{C} .{ }^{10}$ Trasylol (Bayer, Germany) is a polypeptide obtained from bovine lung, with reversible antiproteinase activity against trypsin and chymotrypsin. The higher recoveries of trypsin in duodenal juice in the presence of Trasylol probably result from the inhibition of trypsin digestion by chymotrypsin and by trypsin itself (Fig. 2). Albumin, on the other hand, will reduce trypsin digestion from all the proteolytic enzymes in duodenal juice by providing substrate competition. This probably accounts for the higher recoveries in the presence of albumin. The protein is equally effective at all concentrations between 1 and $8 \mathrm{~g} / \mathrm{l}$.
The intercept of the regression lines (Figs. 3-5) represents the fraction of immunoreactive trypsin in duodenal juice which contains no tryptic activity. This is either trypsinogen, immunoreactive degraded fragments of trypsin, or trypsin bound to pancreatic secretory trypsin inhibitor (PSTI). PSTI-bound trypsin will represent less than $1 \%$ of the total trypsin concentration. ${ }^{11}$ Also, trypsin in duodenal juice is stable at $0^{\circ} \mathrm{C}$ for at least 100 minutes, ${ }^{2}$ so that the concentration of degraded fragments will be minimal in our samples (the samples were assayed within two hours). The intercept probably, therefore, mainly represents 'trypsinogen' concentration. Additional evidence for this is suggested by the higher proportion of immunoreactive trypsin present as 'trypsinogen', in partially activated pure pancreatic juice-that is, $66 \%$ (intercept $607 \mu \mathrm{g} / \mathrm{ml}$; mean total immunoreactive trypsin $926 \mu \mathrm{g} / \mathrm{ml}$ ) compared with controls $32 \%$ (Figs. 3 and 5 ).

A similar proportion of 'trypsinogen' was present in duodenal juice from the controls $(32 \%)$ as from the patients with primary biliary cirrhosis $(32 \%)$. This suggests that trypsinogen conversion is not impaired in this disorder. It was of interest that the mean total immunoreactive trypsin concentration was lower in this group, $457 \pm 306 \mu \mathrm{g} / \mathrm{ml}$, than in controls, $912 \pm 540 \mu \mathrm{g} / \mathrm{ml}$. Higher concentrations were expected in view of the reduced biliary dilution of duodenal juice. The results therefore suggest pancreatic hyposecretion of trypsin. The volumes of duodenal juice aspirated were also low. The presence of bile in the duodenum increases pancreatic enzyme secretion in man. ${ }^{1213} 14$ The chronic absence of bile perhaps induces pancreatic atrophy. In summary, radioimmunoassay measurement of trypsin in duodenal juice is a reliable alternative to enzymatic analysis. The assay can be performed in samples stored with Trasylol; and in pure pancreatic juice trypsinogen can be assayed directly without prior activation. In samples of duodenal juice from patients with primary biliary cirrhosis, the immunoreactive trypsin concentration is low and suggests pancreatic hyposecretion.

We conclude that radioimmunoassay measurement of trypsin in duocenal juice is reliable, and may prove superior to enzymatic analysis. Measurement of both enzymatic activity and immunoreactivity simultaneously may in the future provide additional information on the trypsinogen deficiency states $^{151617}$ where possibly biologically inactive, but immunologically reactive, trypsin may be secreted.

We thank Professor Dame Sheila Sherlock for permission to study patients under her care. GL-B is a Medical Research Council Fellow and JAS is in receipt of an MRC grant. 


\section{References}

${ }^{1}$ Elias E, Redshaw M, Wood T. Diagnostic importance of changes in circulating concentrations of immunoreactive trypsin. Lancet 1977; 2: 66-8.

${ }^{2}$ Müller-Wieland K, Berndt W. Die Bedeutung der Aktivierung und Inaktivierung von proteolytischen Enzymen für die Funktionsdiagnostik des Pankreas. Z Gastroenterol 1967; 5: 234-8.

${ }^{3}$ Hadorn B, Hess J, Troesch V, Verhaage W, Götze H, Bender SW. Role of bile acids in the activation of trypsinogen by enterokinase: disturbance of trypsinogen activation in patients with intrahepatic biliary atresia. Gastroenterology 1974; 66: 548-55.

${ }^{4}$ Rinderknecht H, Friedman R. Effect of bile acids and ionic strength on trypsinogen activation by human enteropeptidase. Biochem Biophys Acta 1978; 525: 200-8.

${ }^{5}$ Rick W. In Bergmeyer HU, ed. Methods of enzymatic analysis, vol. 2, 2nd English edition, Weinheim/New York and London: Verlag Chemie/Academic Press, 1974: 1013.

${ }^{6} \mathrm{Hummel}$ BCW. A modified spectrophotometric determination of chymotrypsin, trypsin, and thrombin. Canad J Biochem Physiol 1959; 37: 1393-9.

${ }^{7}$ Elmslie R. The effect of bile on the activation of trypsinogen and the activity of trypsin in pancreatic juice. $B r$ J Surg 1965; 52: 465-70.

${ }^{8}$ Lowry OH; Rosebrough NJ, Farr AL, Randall RJ.
Protein measurement with the Folin phenol reagent. J Biol Chem 1951; 193: 265-75.

${ }^{9}$ Temler RS, Felber JP. Radioimmunoassay of enzymes of the exocrine pancreas (trypsin, chymotrypsin, chymotrypsinogen). Biochem Biophys Acta 1971; 236: 78-83.

${ }^{10}$ Schroeder DD, Shaw E. Chromatography of trypsin and its derivatives: characterization of a new active form of bovine trypsin. J Biol Chem 1968; 243: 2943-9.

${ }^{11}$ Greene LJ, Rigbi M, Fackre DS. Trypsin inhibitor from bovine pancreatic juice. J Biol Chem 1966; 241 : $5610-8$.

${ }^{12}$ Wormsley KG. Stimulation of pancreatic secretion by intraduodenal infusion of bile-salts. Lancet 1970; 2: 586-8.

${ }^{13}$ Osnes M, Hanssen LE, Flaten O, Myren J. Exocrine pancreatic secretion and immunoreactive secretion (IRS) release after intraduodenal instillation of bile in man. Gut 1978; 19: 180-4.

${ }^{14}$ Forell MM, Otte M, Kohl HJ, Lehnert P, Stahlheber HP. The influence of bile and pure bile salts on pancreatic secretion in man. Scand J Gastrol 1971; 6: 261-5.

${ }^{15}$ Townes PL. Trypsinogen deficiency disease. $J$ Paedr 1965; 66: 275-85.

${ }^{16}$ Townes PL, Bryson MF, Miller G. Further observations on trypsinogen deficiency disease: report of a second case. J Paedr 1967; 71: 220-4.

${ }^{17}$ Morris MD, Fisher DA. Trypsinogen deficiency disease. Am J Dis Child 1967; 114: 203-8. 